\title{
ECONOMIC ANALYSIS AND WATERS QUALITY SEAWEED FARMING (Eucheuma cottonii) IN THE DISTRICT OF BANGKEP
}

\author{
Saharia Kassa ${ }^{1)}$, Bakri Hasanuddin ${ }^{2)}$, Madinawati ${ }^{3)}$ \\ ${ }^{1)}$ Lecturer and Researcher at Department of Agribusiness Faculty of Agriculture. University of Tadulako. Palu. \\ e-mail: saharia_kassa@yahoo.com \\ ${ }^{2)}$ Lecturer and Researcher at Department of Economics. Faculty of Economic. University of Tadulako. Palu. \\ ${ }^{3)}$ Lecturer and Researcher at Faculty of Animal Husbandry and fisheries. University of Tadulako. Palu.
}

\begin{abstract}
Seaweed farming development received support from local government with "Gema Biru Sulawesi Tengah" which makes seaweed commodities became the competitive commodity across sectors in the region. Nowadays, the demand of the dried seaweeds as well as semi-finished products (semi-finished carrageenan) tends to be increased rapidly because they are classified as healthy food. On the other hand, the farmer in the district of Bangkep relatively still being traditional by planting in the territorial which estimated suitable for seaweed. The Study aims to identify the water potential of seaweed farming and to analyze the economic variables that affecting the production of seaweed based on its deployment area. This research is conducted in Bangkep in 4sub-districts area i.e. Bulagisub-district (Peling Peasa, Bulagi and Kambal village), South Bulagi District (Bulagi, Palabatu, and Lolantang village), South Tingkung district (Tinangkung, Bobu and Gangsal village) and Liang district (Apal, binatuli and Liang village). The determination of locations is done purposively with 56 respondents. The data Analysis used are suitability analysis with water measurement and testing of water sample as well as regression analysis. The research shows that the locations of the farms have water quality which suitable with the seaweed, which shown by the result of the physical-chemical measurement parameters that meet with the growing requirements in the range of achievement $74.00-82.67 \%$. Economic aspects show the average income of the seaweed farmers are Rp. 1.614.434. Further variables simultaneously independent (age, education, number of dependents, experience, the amount of expanses, and prices) that affect the production of seaweed, while partially only age, experience, amount of expanses, and prices significantly affect the production on the $t$ value of each are $2.57 ; 3.69 ; 2.49$; and 2.33 .
\end{abstract}

Key Words : Economic variables, farming, seaweed, waters.

\section{INTRODUCTION}

Seaweed (Eucheuma cottonii) has high economic value and very popular in both domestic and export trade because of its usefulness as a raw material that is diverse, both for the pharmaceutical, cosmetics and pharmaceuticals. In addition, seaweed also serve as the source of nutrition that contains carbohydrates (vegetable gum), protein, fat, vitamins and minerals, especially iodine. The problem is that the seaweed cultivation in this area include in the District of Bangkep relatively still traditional with low productivity, the planting is done in the territorial waters that are deemed appropriate and within easy reach of the coastal settlements.

Central Sulawesi province that has a long coastline about $4,013 \mathrm{~km}$ and an area of $89865 \mathrm{~km}^{2}$ of the sea, one of the coastal area is waters where the cultivation of seaweed for the coastal communities is in Bangkep district. The potential of the economic opportunities for the development of seaweed, which is currently a small part has been started to be used by the coastal communities. Total production of seaweed in 2014 amounted to $164,927.50$ tons of wet, this production puts Bangkep district 
as the biggest producer of seaweed in Central Sulawesi province after Parimo, Morowali and District Touna (Kadiskanlut, 2014). Seaweed cultivation development supported by local government with "Gema Biru Sulawesi Tengah" it is also in accordance with the research results of Bank Indonesia that seaweed commodity's position as one of the leading commodity sector in the District of Bangkep (KBI, 2011).

Regarding to the position, at this point seaweed productivity tends to be decreased, area planted to stagnate, even some farmers did not plant at the time of collecting data. The reduced area of people's cultivation in the study area is because the price of the seaweed that very low, it is only about $\mathrm{Rp} \mathrm{5,000-Rp} \mathrm{6,000/Kg} \mathrm{(Interviews}$ with respondents., 2016).

In line with efforts to accelerate economic development associated with "Gema Biru Sulawesi Tengah", basically the farmers of seaweed requires the support information about suitability or the quality of the waters where they cultivate the seaweed in the District of Bangkep. In addition, the market price as a decisive determinant of farmer's income are also important, because it is directly related to the acceptance and feasibility of seaweed farming. The important thing that also important to know, is what are the factors affecting the production of seaweed produced in the research area, therefore, an article on "Economic Analysis and Waters Potential on Cultivation Seaweed (Eucheuma cottonii) in the district of Bangkep" is interesting to be analyzed. This analysis will be very beneficial for the local government, encouraged farmers community in improving productivity, while strengthening the economic fabric of coastal communities to the expansion of plantations and seaweed.

\section{METODOLOGY OF RESEARCH}

The first year of the research aims to get the physical data and chemistry of the waters cultivation of seaweed and to determine the feasibility of their business and what factors influence the production of seaweed. This research is implemented in the District Bangkep in 4 sub-districts, namely District Bulagi represented by (Village Peling Peasa, Village Bulagi, and Village Kambal), Bulagi South (Village Bulagi, Village Palabatu I and the Village Lolantang), South Tinangkung (Village Tinangkung, Bobu, and Village Gangsal), and the District Liang (Apal Village, Liang Village, and Village Binantuli).

The determination of location is done with consideration of proposals on education purposive SKPD Diskanlut District of Bangkep that the site has been being the largest region to produce seaweed in the District of Bangkep. Furthermore, the existing condition of seaweed cultivation time of data collection is also taken into account in determining the location of the research with the hope representation of coastal areas Bangkep district. When referring to the Strategic Plan of Bangkep district, then almost all the coastal district is prepared as a center for the cultivation of seaweed on a regional scale potential development of coastal resources, but only five in districts of the populations grow seaweed at the time when collecting data. The development of seaweed become one of the commodities considered strategic to choose to accelerate the development of Parimo Economic District and Central Sulawesi province, which is also in line with the corridor of MP3EI.

The data field collection is in March-August 2016. Respondents were determined by purposive randomized stratified (stratified random sampling), but still need to be find the respondents who do the planting in the last 4 months, and ultimately the number of respondents from each sample village as much as 4 people bringing the total respondents as many as 56 people. The primary data for social and economic aspects obtained through interviews and observation, and the water quality is obtained by direct 
measurement at the site by taking two points of observation on each of the waters of seaweed farming in 14 sample villages, so the total sample is 28. Secondary data needed either obtained through literature searches and Periodic Annual Research Reports of relevant agencies, among others SKPD Diskanlut and BPS.

Furthermore, analysis of water quality data continued by test in Agrotechnology laboratory, Tadulako, while the economic analysis conducted by the formula (equation) as following:

1. Analysis of Income of Seaweed Farming,

$$
\Pi_{\mathrm{i}}=\mathrm{TRi},-\mathrm{TC} \text {, }
$$

where $\mathrm{i}=$ amount of farmers /Cultivators

$$
\text { Пtot }=\sum \pi \mathrm{i}
$$

2. Analysis of Regression:

$$
\begin{array}{r}
Y=\beta_{\mathrm{o}}+\beta_{1} \cdot X_{1}+\beta_{2} \cdot X_{2}+\beta_{3} \cdot X_{3}+ \\
\beta 4 . D_{1}+\beta_{5} \cdot D_{2}+e_{i} \ldots \ldots \ldots \ldots \ldots \ldots \ldots \ldots . .
\end{array}
$$

Where:

$$
\mathrm{Y}=\text { Seaweed production }(\mathrm{Kg})
$$$$
\beta_{\mathrm{o}} \quad=\text { Intersep }
$$

$\beta_{0}-\beta_{6}=$ Regression coefficient

$\mathrm{X} 1=$ Farmers age (Years)

$\mathrm{X} 2=$ Education (Years)

$\mathrm{X} 3=$ Amount of independent (people)

$\mathrm{X} 4=$ Experience (years)

$\mathrm{X} 5=$ Amount of expanses (buah)

$\mathrm{X} 6=$ Price $(\mathrm{Rp})$

$\mathrm{e}_{\mathrm{i}} \quad=$ Error term

To see the effect of simultaneous F test with the following formula:

$$
\mathrm{F}=\frac{K T R}{K T S}
$$

Where:

$\mathrm{F} \quad=$ Uji Fisher (Fisher test)

KTR = Central Squares Regression

KTS = Central Squares Time

Analysis of Waters Suitability of Seaweed Farming. The analysis is intended to determine the suitability of the waters of waters area suitability for cultivation of seaweed using water suitability indicators. This concept is based on the parameters of biology, physics, and chemistry of water (hidrooceanografi) ecologically is a prerequisite eligibility in seaweed cultivation. Determining the level of water suitability for cultivation of seaweed determined by calculation feasibility level by giving weight to each parameter measured by the results of the literature study and information from experts.

\section{RESULTS AND DISCUSSION}

Bangkep district has been established as one of thelocation of seaweed farming Eucheuma cottoni in Central Sulawesi province with most communities in the coastal district cultivate seaweed, empirically productivity is still low, as well as advanced level of technology among peasant farmers, as well as its market reach is limited to primary commodities with volatile prices, even at the time of field research undertaken tended to decrease (the result observation researcher. 2016). Analysis of economic variables in the cultivation of seaweed Eucheuma cottoni begins with discussion of water quality measurements as follows.

Characteristic of Waters Quality Research Location. Data characteristics of physical and chemical of water quality cropping seaweed in 4 (four) districts in the regionnof Bangkep each presented in Table 1 and Table 2.

Table 1 shows the results of the physical quality analysis of water that will be outlined as follows:

1. Current velocity

Flows are very helpful in supplying and increasing the diffusion of nutrients into plant tissue and cause fluctuations in salinity and small temperature. Besides the strength of the current direction should also be known to determine a general overview of the cultivation area so that the water circulation remains smooth and in control.

The current velocity measurement results are listed in Table 1 by using a kite show flow velocity varies between $0.1 \mathrm{~m} / \mathrm{s}$ to $0.39 \mathrm{~m} / \mathrm{sec}$. As seen from the result data obtained current velocity is still in the category of needed for the growth of seaweed. This is accordance 
with Anggadireja et al., (2006) that the current speed for seaweed cultivation ranges from $0.2-0.4 \mathrm{~m} / \mathrm{sec}$ so that the plant can be cleaned from dirt and nutrient supply can work well.

2. Waters deepness

In addition, the current velocity water depth is another important determinant of physical quality of waters, as they relate to the level of acceptance or the penetration of sun light to support photosynthesis process of plants seaweed. The depth of waters in accordance will facilitate the absorption of food and protected from damage caused by the absorption of direct sunlight (Sudarmi., 2012). The location of seaweed farming, in Bangkep district has a very varied water depths (Table 1) they are in between 3.0 to $35.0 \mathrm{~m}$ started in the village of Pelingpeasa to Bobu village.

Kadi and Atmadja (1988) reported the results of their research that the ideal depth for the growth of seaweed is in Kepulaun Seribu with the basic method is 0.3 to $0.6 \mathrm{~m}$ at the lowest tide. This shows that the depth of the location of seaweed farming in the study site from the sites were partially has a depth of water of seaweed cultivation are in the category of eligible (appropriate) for the growth of seaweed.

3. Waters Brightness

Brightness in the waters of Bangkep District looks different from the relatively brightness level of $3 \mathrm{~m}$ $20 \mathrm{~m}$ (Table 1), it indicates that there is a difference in brightness at various locations cultivation for each sampling point. This condition is suspected because some locations are at a level sufficient depth within and partly is at a level somewhat shallow depths. However, the brightness level is still very good for seaweed cultivation, as proposed by Mubarak et al. (1990) that for seaweed farming activities are ideal, when the brightness level of the water is $>5 \mathrm{~m}$.

\section{Temperature}

Temperature directly affects the lives of seaweed, especially in the process of Photosynthesis, the process of metabolism, and reproductive cycles, fluctuations in very high temperatures will make the plants become stressed and affect the growth rate (Mayunar et al., 1995). The temperature of the water at the sampling point for seaweed cultivation in the District of Bangkep obtained using a temperature gauge thermometer. Data obtained ranged from $31^{\circ} \mathrm{C}$ to $33,7^{\circ} \mathrm{C}$ with average values varied for all sampling locations consisting of $31^{\circ} \mathrm{C}$ to $33,7^{\circ} \mathrm{C}$. The lowest temperature result is in the village of Liang while the highest temperature obtained in the village Binuntuli. In general, the water temperature in the District of Bangkep still within the range of temperatures that promote the carrying seaweed farming activities.

The measurement visually results to the chemical waters quality in aquaculture, seaweed locations can be seen in Table 2.

The results data analysis of chemical quality of the waters in the study area will be described as follows:

1. Nitrat

Table 2 shows the levels of nitrates in the waters of seaweed farming locations ranged from 1.59 to $2.97 \mathrm{ppm}$, which indicates that the nitrogen content is in the range of suitable for seaweed cultivation. Joseph (2004) suggested that the nitrate content range which good for seaweed growth ranged from 0.1 to 3.5 ppm while Kamlasi (2008) states that nitrate can be a limiting factor if the concentration $<0.1 \mathrm{ppm}$ and $>4.5 \mathrm{ppm}$. Based on the data obtained in this study showed levels of nitrate found is relatively small and it is in category of eligible for seaweed cultivation.

\section{Phosfat}

Table 2 shows the phosphate levels at each site ranged from 0.009 to $0.012 \mathrm{ppm}$. The results of the study in line with the opinion of Simanjuntak 
(2006) found relatively fertile waters if the range of nutrient phosphate in sea water normally is 0.10 to $1.68 \mathrm{ppm}$. This shows the locations of seaweed farming in the District of Bangkep especially in some rural locations are in the category of research is still feasible for seaweed cultivation.

3. Salinity

Salinity measurement results of the study sites showed values ranging between 32-34 ppt with the average $33.21 \mathrm{ppt}$, salinity in the area is relatively high and uniform. It is because there is no streams found that will affect the salinity and low rainfall at the time of sampling. The range of salinity obtained in research in all these locations are still in a reasonable range to support the growth of seaweed. This is in accordance with the opinion of Kadi (2006) which states that the range of growth of seaweed in order to thrive in the tropics should have ranged between 32-34 ppt salinity.

4. $\mathrm{pH}$

Measurement of $\mathrm{pH}$ value of waters in District of Bangkep using a portable $\mathrm{pH}$ meter, indicates the range within 7.46 to 7.90 with the lowest average value is 7.46 while the highest average value is 7.90 . The $\mathrm{pH}$ value Tinangkung is low for the village while the highest values is in the Village Bulagi. The results showed that $\mathrm{pH}$ values vary at each sampling location, but the overall value of the average utilization of waters of seaweed farming zone, is within the range that is supportive to undertake cultivation of seaweed.

Analysis of Economics of Seaweed Farming. The economic aspects of seaweed cultivation were analyzed by analysis of revenue and regression analysis to determine what factors influence the production of seaweed, which will be described as follows:

Analysis of Income Seaweed Farming. Analysis of feasibility of seaweed cultivation is done to determine how much revenue earned by seaweed farmers in the research area. The analysis showed that the average income received by seaweed farmers is Rp. 2,411,143/planting season. This is in line with the results of research conducted Marhawati and Hasanuddin (2010), suggests that the income received seaweed farmers ranged Rp. 2.000.000 Rp. 3.000.000,-. The amount of revenue is derived by reference to the average of seaweed obtained during one growing season amounted to $430.73 \mathrm{~kg}$ with an average selling price of $\mathrm{Rp} 5.594 / \mathrm{kg}$ of dried seaweed. A number of income received by the respondents in the study area is still very low even if the implicit costs tend deficit (family labor) involved in seaweed farming activities are also taken into account.

Analysis of Income Seaweed Farming. Analysis of feasibility of seaweed cultivation is done to determine how much revenue earned by seaweed farmers in the research area. The analysis showed that the average income received by seaweed farmers is Rp 2,411,143/planting season. This is in line with the results of research conducted Marhawati and Hasanuddin (2010), suggests that the income received seaweed farmers ranged Rp. 2.000.000 - Rp. 3.000.000, -. The amount of revenue is derived by reference to the average of seaweed obtained during one growing season amounted to 430.73 $\mathrm{kg}$ with an average selling price of Rp. $5.594 / \mathrm{kg}$ of dried seaweed. A number of income received by the respondents in the study area is still very low even if the implicit costs tend deficit (family labor) involved in seaweed farming activities are also taken into account.

\section{Analysis of Various Factors that Influencing Seaweeds Production.} Regression analysis is used to determine the effect of independent variables (age, education, Number of Dependents Family, Experience, Total Landscape, and Price) on the production of seaweed. This study uses a significance level of $5 \%$. The results of the data analysis are shown in Table 3. 
Table 1. Waters Physical Quality Data of Seaweed Farming Area inthe District of Bangkep

\begin{tabular}{|c|c|c|c|c|c|c|c|c|c|c|c|c|c|}
\hline \multirow{3}{*}{ No } & \multirow{3}{*}{$\begin{array}{c}\text { Variabels } \\
\text { Measurements }\end{array}$} & \multicolumn{12}{|c|}{ Locations } \\
\hline & & \multicolumn{3}{|c|}{ Kec. Bulagi } & \multicolumn{3}{|c|}{ Kec. Tinangkung Selatan } & \multicolumn{3}{|c|}{ Kec. Bulagi Selatan } & \multicolumn{3}{|c|}{ Kec. Liang } \\
\hline & & $\begin{array}{l}\text { Peling } \\
\text { Peasa }\end{array}$ & $\begin{array}{c}\text { Kel. } \\
\text { Bulagi }\end{array}$ & $\begin{array}{c}\text { Kamba } \\
1\end{array}$ & $\begin{array}{l}\text { Tinag } \\
\text { kung }\end{array}$ & Gansal & Bobu & Bulagi & $\begin{array}{c}\text { Lolan } \\
\text { tang }\end{array}$ & $\begin{array}{c}\text { Pala } \\
\text { batu I }\end{array}$ & Apal & Liang & $\begin{array}{c}\text { Binun } \\
\text { tuli }\end{array}$ \\
\hline 1. & $\begin{array}{l}\text { Current } \\
\text { Velocity } \\
\text { (m/det) }\end{array}$ & 0,15 & 0,10 & 0,10 & 0,2 & 0,3 & 0,15 & 0,15 & 0,3 & 0,10 & 0,39 & 0,24 & 0,14 \\
\hline 2. & Deepness (m) & 3 & 10 & 12 & 10 & 13 & 35 & 30 & 20 & 30 & 32 & 33 & 15 \\
\hline 3. & Brightness (m) & 3 & 6 & 8 & 6 & 7 & 17 & 15 & 15 & 15 & 20 & 20 & 7 \\
\hline 4. & $\begin{array}{l}\text { Temperature } \\
\left({ }^{0} \mathrm{C}\right)\end{array}$ & 31,5 & 32 & 32 & 31,5 & 31,5 & 32 & 30,7 & 31,4 & 31,7 & 31,1 & 31 & 32,7 \\
\hline
\end{tabular}

Source: Analysis Result of Primer Data, 2016.

Table 2. Waters Chemical Quality Data of Seaweed Cultivation Area in District Bangkep

\begin{tabular}{|c|c|c|c|c|c|c|c|c|c|c|c|c|c|}
\hline \multirow{3}{*}{ No } & \multirow{3}{*}{$\begin{array}{c}\text { Variabels } \\
\text { Measure } \\
\text { ments }\end{array}$} & \multicolumn{12}{|c|}{ Locations } \\
\hline & & \multicolumn{3}{|c|}{ Kec. Bulagi } & \multicolumn{3}{|c|}{ Kec. Tinangkung Selatan } & \multicolumn{3}{|c|}{ Kec. Bulagi Selatan } & \multicolumn{3}{|c|}{ Kec. Liang } \\
\hline & & $\begin{array}{l}\text { Peling } \\
\text { Peasa }\end{array}$ & $\begin{array}{c}\text { Kel. } \\
\text { Bulagi }\end{array}$ & Kambal & $\begin{array}{l}\text { Tinag } \\
\text { kung }\end{array}$ & Gansal & Bobu & $\begin{array}{c}\text { Bula } \\
\text { gi }\end{array}$ & $\begin{array}{c}\text { Lolanta } \\
\text { ng }\end{array}$ & $\begin{array}{c}\text { Pala } \\
\text { batu } 1\end{array}$ & Apal & Liang & $\begin{array}{c}\text { Binuntul } \\
\mathrm{i}\end{array}$ \\
\hline 1. & Nitrat (ppm) & 2,23 & 1,59 & 2,27 & 2,10 & 2,46 & 2,37 & 1,99 & 2,98 & 2,13 & 2,13 & 2,97 & 2,63 \\
\hline 2. & Fosfat (ppm) & 0,011 & 0,011 & 0,007 & 0,009 & 0,012 & 0,010 & 0,009 & 0,010 & 0,009 & 0,010 & 0,010 & 0,010 \\
\hline 3. & $\begin{array}{l}\text { Waters Salinity } \\
\text { (ppt) }\end{array}$ & 32 & 30 & 29,5 & 32 & 32 & 31,5 & 31 & 30 & 27 & 30 & 32 & 30 \\
\hline 4. & $\mathrm{pH}$ & 7,74 & 7,85 & 7,81 & 7,9 & 7,67 & 7,46 & 7,42 & 7,64 & 7,78 & 7,41 & 7,04 & 7,51 \\
\hline
\end{tabular}


Table 3. Analysis of Variance Independent Variables which Affecting The Production of Seaweed in The District of Bangkep, 2016

\begin{tabular}{rlrrrrr}
\hline & Model & Sum of Squares & Df & Mean Square & \multicolumn{1}{c}{ F } & \multicolumn{1}{c}{ Sig } \\
\hline 1 & Regression & 1070976.477 & 6 & 178496.080 & 23.807 & $.000^{\mathrm{a}}$ \\
& Residual & $367378 ; 505$ & 49 & 7497.521 & & \\
\hline & Total & 1438354.982 & 55 & & & \\
\hline
\end{tabular}

Source: Data Primer After Analyzed, 2016.

Table 4. The Results Analysis of Partial Independent Variables of Seaweed Production at Regional Research, 2016

\begin{tabular}{lrrrrrr}
\hline \multirow{2}{*}{ Model } & \multicolumn{2}{c}{ Unstandardiced Coeffisients } & Standardiced Coeffisients & & & \multirow{2}{*}{ S } \\
\cline { 2 - 4 } \multicolumn{1}{c}{ B } & \multicolumn{1}{c}{ Std Error } & Beta & & & \\
\hline 1 Constant) & 295.813 & 160.208 & & & 1.846 & .071 \\
Umur & 1.395 & 2.079 & & -.255 & -2.571 & .505 \\
Pendidikan & 4.755 & 5.288 & .046 & .899 & .373 \\
JTK & 12.039 & 12.097 & .054 & .695 & .325 \\
Pengalaman & 22.972 & 5.757 & .361 & 3.691 & .000 \\
JB & 8.164 & 1.487 & & .240 & 2.492 & .000 \\
Harga & 26.977 & 21.808 & & .231 & 2.334 & .000 \\
\hline
\end{tabular}

Source: Data Primer After Analyzed, 2016.

Table 3 shows that the value of $\mathrm{F}_{\text {count }}=23.81$ with sig value $=0.000<0.01$, means that the independent variables simultaneously significant effect on the production of seaweed. The coefficient of determination R2 worth 0,745 or $74.5 \%$ indicates that the variation amount of seaweed production (Y) is influenced by age, education, number of dependents, experience, and the amount of expanses; while $25.5 \%$ is determined by other factors not included in the model. Furthermore, to determine the influence of each independent variable of the production can be seen in Table 4.

Referring to Table 4, the results of the analysis can be written in mathematical models as follows:

$\mathrm{Y}=295,81-0,255 \mathrm{X}_{1}+0,046 \mathrm{X}_{2}+0,054$ $X_{3}+0,361 X_{4}+0,240 X_{5}+0,231 X_{6}$

The resulting mathematical equations indicate that if $\mathrm{X} 1, \mathrm{X} 2, \mathrm{X} 3$, $\mathrm{X} 4, \mathrm{X} 5, \mathrm{X} 6$ (age, education, number of dependents, the experience, the amount of expanses, and price) $=0$ then the production of seaweed produced $=295.81 \mathrm{Kg}$ seaweed dry/planting season. Table 4 also shows that the partial age (X1) negatively correlated to the production of seaweed with the coefficient of -0.255 , which means that each additional $1 \%$ age would reduce production by $25 \%$. Variable experience (X4) significantly affected the production of seaweed with the coefficient of 0.361 , which means that each additional experience trying seaweed $1 \%$ would increase production by $36 \%$. Similarly, the amount of expanses (X5) and price (X6) that affect the production of seaweed indicated by the regression coefficient each worth 0.240 and 0.231, which means that every additional amount of expanses of $1 \%$ would increase production by $24 \%$ and prices gives an indication that any seaweed prices rose by $1 \%$ would increase production of seaweed as $23 \%$. This is confirmed by field observations that the seaweed farmers will be motivated to increase the amount of expanses of seaweed cultivated along with rising prices of seaweed. 


\section{CONCLUSION AND RECOMMENDATION}

Based on the results of water quality analysis and economic analysis seaweed farming in the District of Bangkep the coastal district in 4 district of Bangkep result that water quality complies with the requirements for seaweed cultivation characteristics shown by figures from 74.00 to $82.67 \%$. The economic analysis shows the average production of seaweed produced a crop cultivators for $430.73 \mathrm{~kg}$ of dried seaweed with an average price of
$\mathrm{Rp} 5,594 / \mathrm{kg}$, then the income of $\mathrm{Rp} 2411.143$.

The analysis showed also that the simultaneous variables of age, education, number of dependents, the experience, the amount of expanses, and prices affect the production of seaweed, but only partially age, experience, the amount of expanses, and prices showed significant effect on the production of seaweed. Further recommended that no guidance is integrated in optimizing the potential of coastal resources in the cultivation of seaweed such as the availability of seeds when needed, as well as more favorable market access of farmers and appropriate cultivation techniques.

Acknowledgements. Part of The Research Result of Grant Research MP3I, DP2M, 2016.

\section{REFERENCES}

Anggadiredja, J.T. dan Zatnika, A., 2006. Agribusiness Development Seaweed Sustainable: Beginning of The Market, Ends In The Market. Workshop on Development of National Seaweed and Seaweed Conservation Commission of Indonesia in Jakarta

Kadi A dan Admajaya WS. 1988. Seaweed (Algae). Research and Development Center for Oceanology. LIPI. Jakarta: pages. 71.

Kadi, A. 2006. Suitability Waters Klabat Bangka Island to Land Seaweed. Journal of Fisheries Science 7 (1): 65-70.

Kadiskanlut dalam Anonim. 2012. Final Report. Seaweed Development Masterplan in Central Sulawesi. Kadiskanlut, 2014. Sulteng Prioritaskan Tujuh Komoditi Unggulan Kelautan Perikanan KBI (Office Bank Indonesia) Tahun 2011. Determination Research Commodities of UMKM in Central Sulawesi.

Kamlasi Y. 2008. Ecology and Biological Assessment for Aquaculture Development Seaweed (Eucheuma cottoni) in the District of West Kupang. Kupang Regency East Nusa Tenggra [Thesis]. Bogor: Graduate, Institute of Agriculture Bogor.

Mappatoba, Laapo A, Eka Rosyida. 2009. Analysis of Land Use Water for Seaweed Cultivation use Ecological Footprint in the Cluster Approach Salabangka Island, Morowali District. The Research Report Research Institutions Tadulako University.

Mappatoba dan Hasanuddin. 2010. Mapping Keraginan Prototype and Manufacture Diversification Processed Seaweed to Increase Community Income Salabangka Island Coastal Cluster Morowali District. Reports Competitive Research Grant Research University Tadulako.

Mayunar, Purba, R., dan Imanto, P.T. 1995. Site Selection of Location for Marine Fish Farming. Technology Business Meeting Proceedings Correctional Keramba cage Share Marine Aquaculture. Fisheries Research and Development Center. Research and Development Agency of Agriculture and Agri-Business Club FKPPA.

Mubarak, H., Ilyas, S., Ismail, W., Wahyuni, I.S.,Hartati, S.H., Pratiwi, E., Jangkaru, Z., \& Arifuddin, R. 1990. Technical Instructions seaweed cultivation. Fisheries Research and Development Center. PHP/KAN/PT/13/1990. Jakarta. 93 pages.

Mubarak, H. 1982. Seaweed Cultivation Techniques. Marine Aquaculture Technical Meeting Proceedings. Directorate General Fishery. P 41-47. 
Simanjuntak, M., 2006. Levels of Phosphate, Nitrate and Silicate Relation with Fertility Waterway Mahakam Delta, East Kalimantan. Oceanographic Research Center Lipi. Jakarta.

Sudarmi, 2012. Strategy Development of Seaweed Farming (Kappaphycus Alvarezii) Sustained in Barru [thesis]. Makassar: University Muslim Indonesia.

Yusuf, M.I., 2004. Production, Growth and Content of Seaweed Kappapphycus Alvarezii are Cultivated with Air Systems Media and Tallus Different Seeds. (dissertation). Graduate Program Hasanuddin University. Makassar. 116 pages. 